\title{
Lakes Ecosystem Responses to Human Pressures a Case Study in Southwestern Romania
}

\author{
Oana Mititelu-Ionuș ${ }^{1 *}$, Claudia Ionelia Goga ${ }^{2}$, Daniel Simulescu ${ }^{3}$ \\ ${ }^{1}$ Department of Geography, Faculty of Sciences, University of Craiova, 13 A.I. Cuza Street, 200585 Craiova, Romania \\ ${ }^{2}$ Section of Natural Sciences, The Oltenia Museum, 8 Popa Șapcă Street, 200416 Craiova, Romania \\ ${ }^{3}$ National Agency for Natural Protected Areas, Dolj Territorial Service, Craiova, Romania
}

Received: 23 April 2020

Accepted: 14 August 2020

\begin{abstract}
Freshwater ecosystems have long been affected by numerous types of human interventions that have a negative impact. Ecosystem disturbance constitutes the worst aquatic response to anthropogenic pressures. The research was initiated by identifying the human pressures on the lakes' ecosystem, the main objective being to establish, quantify and diminish the aquatic ecosystem responses. The case study was applied in the suburban area of Craiova city for a natural protected area. The chosen methodology is based on the analysis of the response of the 10 ten lakes located along Preajba Valley to human pressures from two perspectives: morphometric parameters of the lakes and indicators of the aquatic condition. For this purpose, a statistical analysis using Google Earth and GIS tools was conducted. The research was completed by field observations during 2009-2019. The results of the study draw attention to the lacustrine surface, its size decreasing from 28 ha in 2009 to 27 ha in 2019. The aquatic vegetation response was completed by determining the tendency of the vegetation extension (which has been ascending for Lakes II, III, VI and X). Following the interpretation of quantitative biocenotic indices, it can be concluded that the species Carassius gibelio is constant (Frequency-86.8\% and Abundence-51.8\%), being closely followed by Perca fluviatilis and Lepomis gibbosus as accessory species. Our results support the evidence that the high $\mathrm{pH}\left(8.2 \mathrm{pH}\right.$ unit), fixed residue $\left(384 \mathrm{mg} / \mathrm{dm}^{3}\right)$, $\mathrm{NO}^{2}\left(0.124 \mathrm{mg} / \mathrm{dm}^{3}\right), \mathrm{NO}^{3}\left(16.28 \mathrm{mg} / \mathrm{dm}^{3}\right)$ and $\mathrm{CCOCr}\left(49.7 \mathrm{mg} / \mathrm{dm}^{3}\right)$ confirms the high degree of eutrophication in 2019. The paper suggested the assessment of lakes responses to human pressures as a support tool for sustainable lake ecosystems management in suburban areas.
\end{abstract}

Keywords: lake, human activities, degradation, aquatic ecosystem, Preajba Valley

\section{Introduction}

With continuing economic growth and climate change [1], lake abundance and surface areas

*e-mail: oana_ionus@yahoo.com

throughout the world have been threatened by many factors, including human and environmental disruptions $[2,3]$. The natural disturbance regimes play an important role in creating and sustaining habitat and biological complexities on the landscape [4]. Landscape disturbance often constitutes the first anthropogenic signal in aquatic records. 
The understanding of human-environment interactions at local scale is important in order to understand environmental changes, and it is particularly relevant to the scale of action that controls human development [5]. Given the rapid advancement of urbanization, the sustainable development of suburban areas, including water conservancy projects, has received more and more attention [6-8]. Aquatic ecosystems are subject to spatiotemporal variations that are important to be quantified and understood for a proper assessment of their diversity and complexity [9].

Lakes in highly populated or intensively cultivated areas have experienced increased nutrient loading. Management strategies aimed at reducing the sources of these excess nutrients, such as fertilizer runoff or sewage outflows, can largely mitigate the increases in nitrogen and phosphorus levels [10]. Eutrophication is the primary worldwide water quality issue. Reducing excessive external nutrient loading is the most straightforward action in mitigating eutrophication, but lakes often show signs of recovery in the years following external load reduction [11]. Additionally, vulnerability isn't only attributed to natural ecosystem disturbances, but can also result from the interaction between natural and human activities [12].

Land use and hydrological planning at basin scale are essential complements to traditional, local and disconnected restoration measures in order to successfully preserve and restore stream ecosystem integrity, biodiversity, longitudinal and lateral connectivity [13]. Hydro-morphological alteration could have a more clear relationship with aquatic communities. The construction of dams and reservoirs disturbs the natural functioning of many streams and rivers [14]. There are broad similarities in patterns of ecosystem alterations related to the extensive development of dams and water management infrastructure [15]. In addition to the landscape-scale threat posed by dams, the freshwater habitat alteration within the ecoregions is a local-scale risk factor for the loss of the native species toss, the degree of which serves to further identify where and how protection and restoration actions may be prioritized [16].

The inclusion of novel eco-evolutionary ecosystem and social-ecological dynamics arise from the adaptive responses of organisms and ecosystems to global environmental change and act at different integration levels and different time scales [17, 18].

The influence of anthropogenic processes on the natural environment may, therefore, be strongly associated with the ability of governments to adhere to and enforce standards of national and international quality [19]. The selection principles, the conflicts (natural, anthropogenic and legal) are considered focuses of planning for the protected territories [20].

Most protected areas are not isolated landscape elements, but rather members of networks that contribute to current and future human wellbeing at a wide variety of scales [21]. Studies on protected areas monitoring using remote sensing are mainly focused
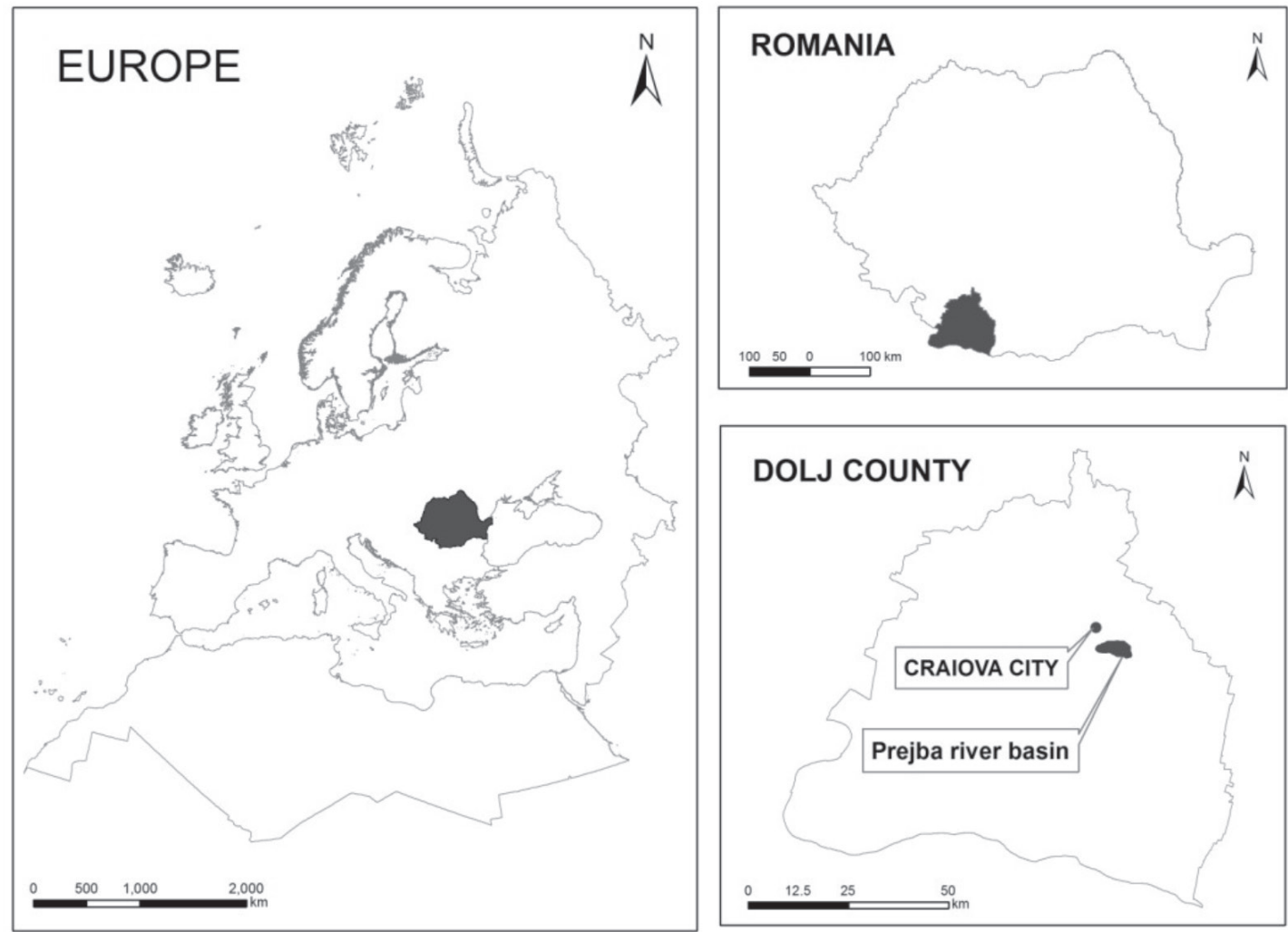

Fig. 1. Location of the study area in the European context. 
Table 1. Studies on lakes ecosystem and human pressure and their theoretical background.

\begin{tabular}{|c|c|c|}
\hline \multirow{2}{*}{$\begin{array}{c}\text { Researcher/s } \\
\text { (Publishing year) }\end{array}$} & \multicolumn{2}{|c|}{ Theoretical background } \\
\hline & Issues & Approaches \\
\hline $\begin{array}{l}\text { Liermann et al. } \\
\text { (2012) [16] }\end{array}$ & $\begin{array}{c}\text { Dam obstruction for global freshwater fish } \\
\text { diversity }\end{array}$ & Restoration actions \\
\hline Qiao (2012) [7] & Sustainable development of suburban areas & Water conservancy projects \\
\hline $\begin{array}{l}\text { Nagendra et al. } \\
\text { (2015) [22] }\end{array}$ & Anthropogenic pressures in protected areas & $\begin{array}{l}\text { Land cover/habitat conversion, land cover/habitat modification, } \\
\text { habitat fragmentation and changes in plant community structure }\end{array}$ \\
\hline $\begin{array}{c}\text { Cumming }(2016) \\
{[21]}\end{array}$ & Relevance and resilience of protected areas & $\begin{array}{l}\text { Periodically re-evaluate, re-negotiate, and re-envision } \\
\text { of protected areas social and ecological roles }\end{array}$ \\
\hline $\begin{array}{l}\text { Dearing et al. } \\
(2016)[5]\end{array}$ & Human-environment interactions & Spatio-temporal variability and scaling \\
\hline $\begin{array}{l}\text { Lürling et al. } \\
(2016) \text { [11] }\end{array}$ & Lakes eutrophication & Reducing excessive external nutrient loading \\
\hline $\begin{array}{c}\text { Elizbarashvili et al. } \\
\text { (2019) [20] }\end{array}$ & Natural and anthropogenic conflicts & Planning for the protected territories \\
\hline $\begin{array}{l}\text { Liu et al. (2019) } \\
{[17]}\end{array}$ & Ecological vulnerability of lakes & Remote sensing and GIS technology \\
\hline $\begin{array}{l}\text { Wang et al. (2019) } \\
\text { [3] }\end{array}$ & $\begin{array}{l}\text { Lakes change in large cities under climate } \\
\text { change and anthropogenic activities }\end{array}$ & Remote sensing and statistical analyses \\
\hline
\end{tabular}

on change detection, biodiversity conservation, and the impact of climate change [22, 23]. Previous researches have the disadvantage of approaching issues from a single perspective (Table 1), without specifying the cause-effect correlations or to look at the whole suburban' space of lakes ecosystem, protected areas and human pressures.

Considering the above the aims of this study are: 1) to develop a dynamic evaluation method for Preajba Valley Lakes' morphometry using Remote Sensing and GIS over longer time scales; 2) to establish spatial and temporal distribution of vegetation extension and fish abundance within the lakes; and 3) to analyse the water quality of the lakes and of the Preajba stream; as well as the relationship between these trends and human pressures.

\section{Material and Methods}

\section{Study Area and Human Pressures Description}

The aquatic natural protected area of national interest "Preajba-Făcăi Lacustrine Complex" (Code site 2,394) is situated in the South-West of Romania, Dolj County, more precisely in the South-East of Craiova city (Fig. 1), having the following coordinates $44^{\circ} 16^{\prime} 20^{\prime \prime}$ lat. $\mathrm{N}$ and $23^{\circ} 50^{\prime} 30^{\prime}$ ' long. E (Fig. 2) [24]. The Preajba stream is $6 \mathrm{~km}$ long and its catchment area has $14.85 \mathrm{sq} \mathrm{km} \mathrm{[25].} \mathrm{The} \mathrm{chain} \mathrm{of} \mathrm{lakes} \mathrm{was} \mathrm{built} \mathrm{during} \mathrm{the}$ communist regime (1976-1979) with the stated purpose of serving as a recreational area for the residents of the nearby municipality. At present, the total area of the lacustrine complex is about 27.77 hectares, being in a continuous increase due to the lakes' warping and the extension of vegetation.

While the effects of humans on the Preajba Valley landscape are relatively easy to demonstrate, the earliest signals of human-induced changes in the structure and functioning of aquatic ecosystems need a very careful investigation. Therefore, this is a holistic study that takes into account multiple aspects: the kind of pressure, the scale, and the response variable.

The previous research on human pressures in the Preajba catchment area [26, 27] used a 1.5 sq. km grid for calculating and comparing the artificialization index of the landscape. The results showed an upward dynamic of the artificialization index: 7 polygons with values between $32.04-54.11 \%$ in 2014 and 2 polygons in 2009. The anthropogenic areas (residences, household annexes, access roads etc.) increased by $22 \%$, which automatically led to a shrinkage of natural areas. Due to the position along the valley and the low degree of accessibility, Lake I, Lake II, Lake III and Lake VI are spared from circulation along the dam. At the opposite pole, i.e. the most popular dams are those of Lakes II (for locals), Lake IV and Lake VII (for tourists) [28].

The environmental conflict of Preajba lacustrine complex is characterized by the following dimensions: the spatial dimension or place of event; the temporal dimension or time event; the environmental dimension and the socio-economic one (Fig. 3). Taking into consideration that results may vary and depending on the aspect used to estimate the aquatic ecosystem' responses, we decided to use both lakes' morphometry and aquatic condition indicators as research methods (water quality, vegetation and fish). 


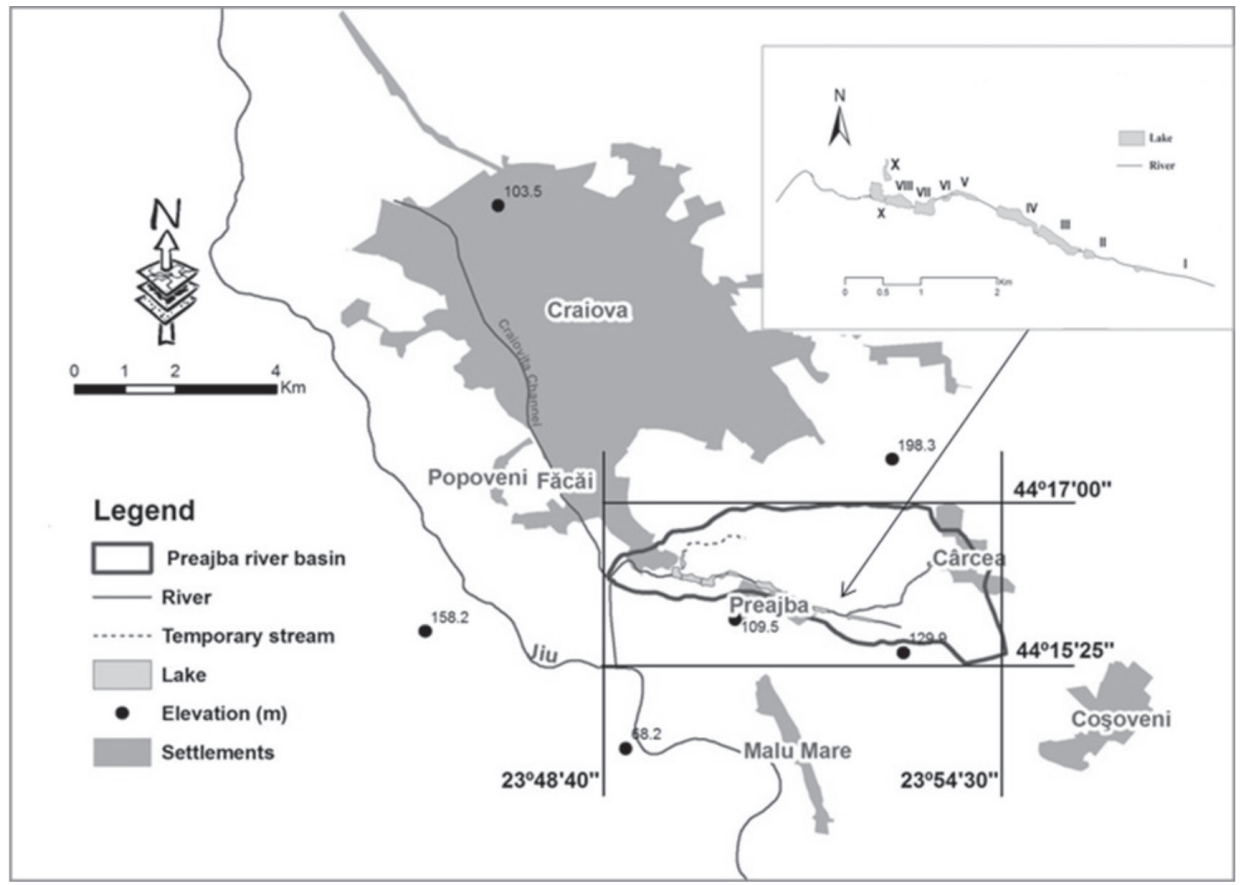

Fig. 2. Study area: the Preajba river basin and lakes (processed after Avram and Ionuș, 2015).

Given the important ecological and socioeconomic role of the Preajba Valley Lakes, long-term investigations (ten years) are of paramount importance in order to understand the response of the lake's ecosystem to human pressures. To this end, we will analyse the symbiotic relationship that exists between the environment and the surrounding anthropic area, between the habitat protection and the particularities of the study area. Subsequently, all the data will be validated by field observations.
Morphometric Parameters of the Lakes

In general, ecological variability increases as spatial and temporal scales become smaller. In this context, our study, provides an alternative way of observing spatial (from upstream to downstream, along the Preajba Valley) and temporal (during 2009-2019) variability by extraction the perimeter and the surface of the ten lakes on satellite images using Google Earth PRO. The lakes were annually vectorised based on the images

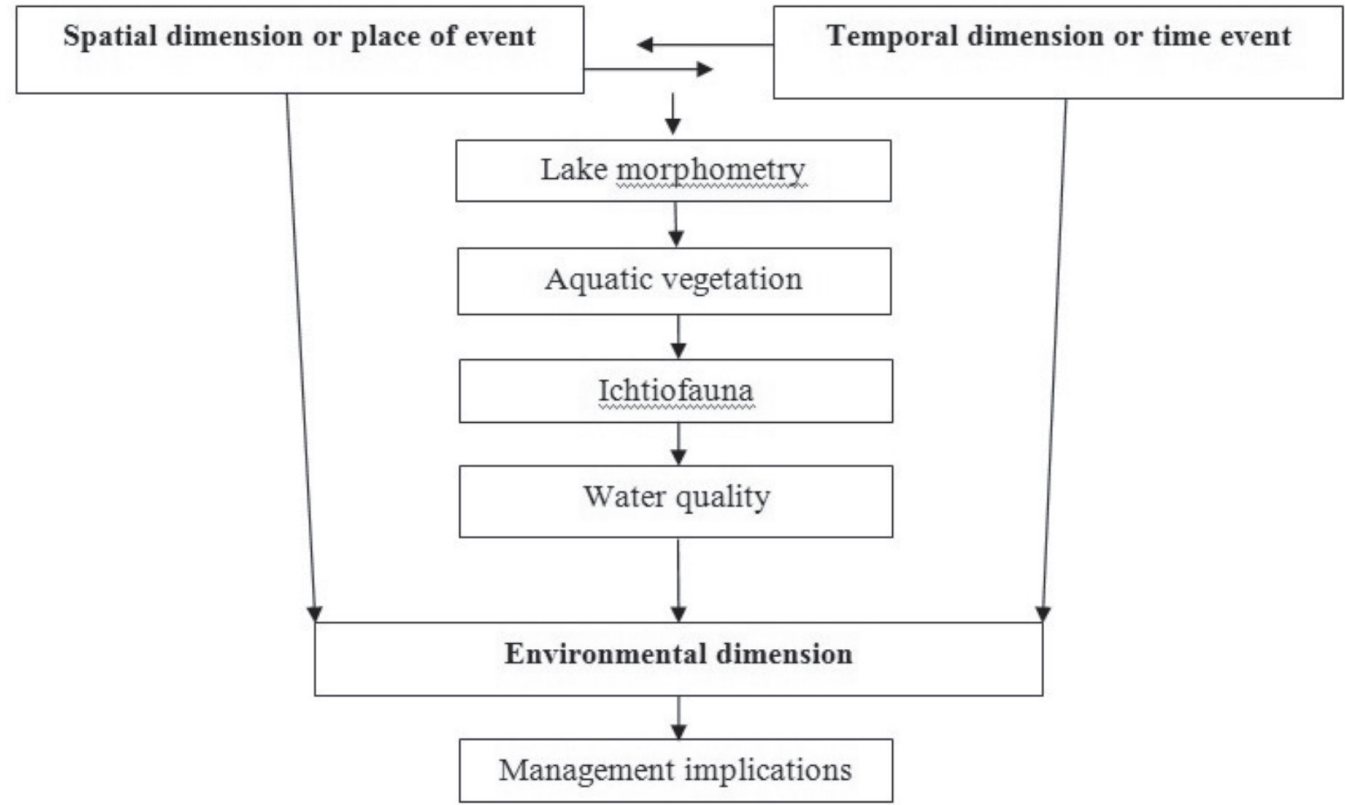

Fig. 3. Schematic flowchart of research methodology. 
corresponding to the month of March, a period in which the riparian vegetation is not extended, thus allowing for contour delimitation.

\section{Indicators of the Aquatic Condition}

In order to evaluate the human impact on the quality of the aquatic ecosystem, an extensive research program was carried out in field observations and ichthyofaunistic research (during 2009-2019), including water sampling from Lake VII for physico-chemical analyses.

Lake VII was chosen for water quality measurements following the determination of its morphometric parameters. At the same time, its protection was also taken into consideration based on the 'protected area' status of the study area and on the socio-economic benefits of this lake (fishing and tourism). The physicochemical analysis was carried out ex-situ by Quality laboratory of the Dolj Environmental Protection Agency, on the samples taken by the authors of this study in October 2014 and November 2019, months in which the results obtained could not be influenced by the development of hydrofile vegetation. The quality parameters targeted were $\mathrm{pH}$, fixed residue, $\mathrm{NO}_{2}, \mathrm{NO}_{3}$ and $\mathrm{CCOCr}$, as reference indicators of eutrophication of the stagnant aquatic ecosystems.

Concerning the aquatic vegetation, this research uses the extrapolated index of insularity (the share of hydrophilic vegetation out of the total lacustrine surface), representing both a visual and value parameter. The field research and Google Earth PRO data extraction for vegetation were performed in May of each year of the study period.

The collection of the ichtiological material was carried out seasonally (except in winter) by using 3 monofilament nets, with lengths between 50 and
$100 \mathrm{~m}$, and the mesh size ranging from 40 to $60 \mathrm{~mm}$. The 832 individuals collected, weighing between $90 \mathrm{~g}$ and $422 \mathrm{~g}$, came from both personal catches with monofilament net, and amateur rod fishing in the area. The ichtiological material was subjected to taxonomic determination, each species being analysed according to the lake.

Humans have direct effects on species that alter aspects of their population structure ranging from age distributions to overall abundance [29]. The ichtiological material in Lake VII was also ecologically analysed regarding the quantitative biocenotic indices (frequency and abundance), according to the following formulas: $\mathrm{F} \%=\mathrm{p} / \mathrm{P} \times 100$ waves $(\mathrm{p}-$ number of samples in which a species occurs; $\mathrm{P}$ - total number of samples observed) and $\mathrm{A} \%=\mathrm{n} / \mathrm{N} \times 100$ waves ( $\mathrm{n}$ - number of individuals of a species; $\mathrm{N}$ - number of individuals of all species in the samples) [30, 31].

To better understand the deterioration of the lacustrine ecosystem in a protected area, we make use of a methodology which implies the analysis of the weak points in the management strategy that should be essential in counteracting human pressures and mitigating their effects.

\section{Results and Discussion}

The human pressures observed on Preajba Valley Lakes, over the past 10 years, are highly variable in time and space. These refer to the input of sewage into the freshwater systems (Preajba stream); the hydromorphological alterations (building dams on Lake IV and VI, blocking the spillways of Lakes II, III and VII), the eutrophication-related turbidity and the loss of biodiversity (Lakes II, III, IV, VII and VIII) (Fig. 4).

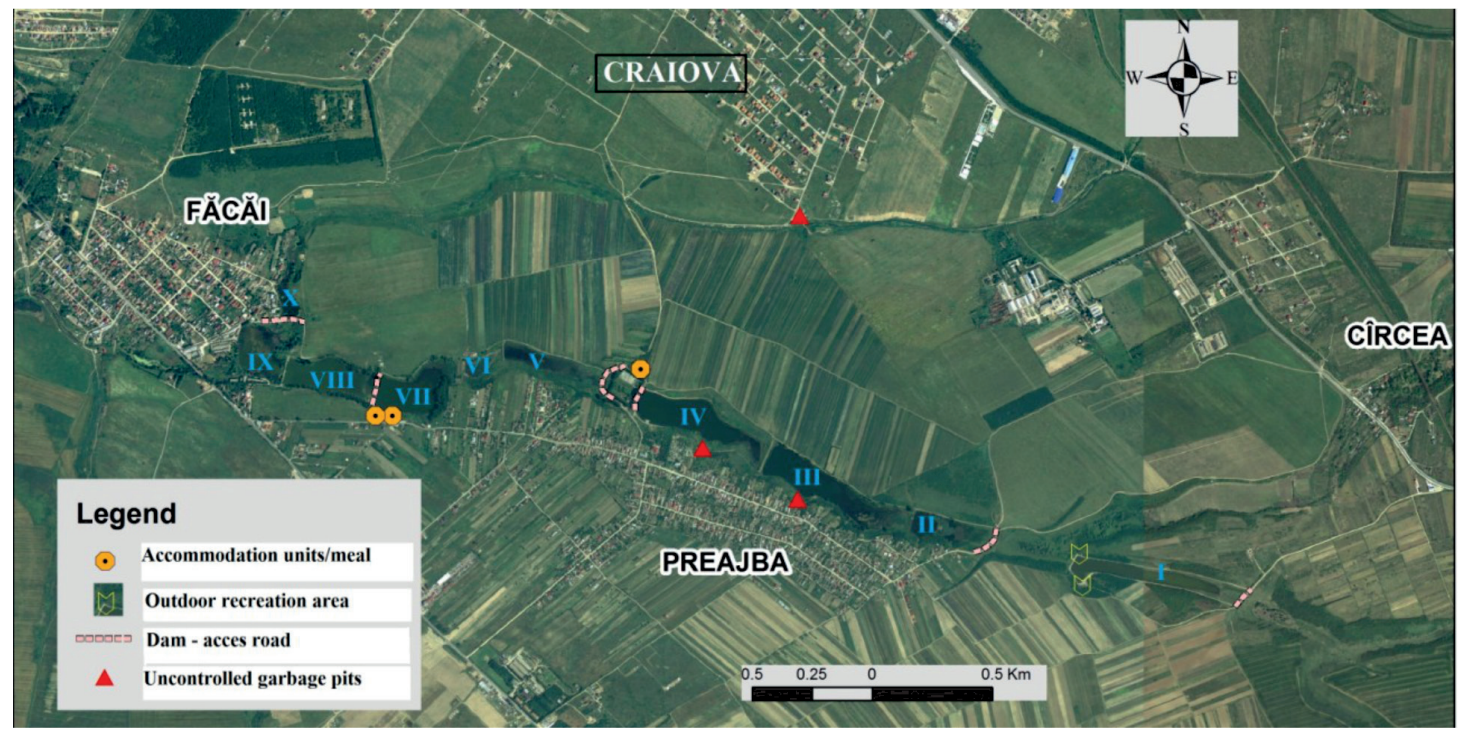

Fig. 4. Spatial inventory of the main human activities within the Preajba river basin (field observations and Google Earth PRO, accessed April 2019). 
Table 2. The dynamics of Preajba Valley Lakes surfaces.

\begin{tabular}{|c|c|c|c|}
\hline \multirow{2}{*}{ Lake number } & \multicolumn{3}{|c|}{ Surface (ha) } \\
\cline { 2 - 4 } & 2009 & 2014 & 2019 \\
\hline I & 0.94 & 2.95 & $\mathbf{3 . 1 7}$ \\
\hline II & 1.22 & 1.61 & 1.61 \\
\hline III & 6.09 & 5.36 & $\mathbf{5 . 5 1}$ \\
\hline IV & 5.95 & 4.82 & $\mathbf{6 . 1}$ \\
\hline V & 1.39 & 0.88 & $\mathbf{0 . 6 1}$ \\
\hline VI & 0.66 & 0.036 & - \\
\hline VII & 3.78 & 3.63 & 3.63 \\
\hline VIII & 3.76 & 3.58 & $\mathbf{4 . 1 6}$ \\
\hline IX & 3.13 & 2.1 & 2.1 \\
\hline X & 1.14 & 0.87 & 0.87 \\
\hline Total surface: & 28.06 ha & 25.34 ha & 27.77 ha \\
\hline
\end{tabular}

(Data source: Google Earth PRO data extraction)

\section{Lake Morphometry Response}

The total area of the lacustrine complex is in a continuous decrease due to the warping and the extension of vegetation. The measurements made with Google Earth PRO revealed that the total surface of the Preajba Valley Lakes oscillated throughout the years: 28 ha (2009); 25 ha (2014); 27 ha (2019) (Table 2). The reduced values in 2014 were due to the climatic conditions (drought) that negatively influenced the supply springs of the lakes and positively favoured the evaporation at the level of the lake surface.

In the 10 years of study, by means of satellite images and field visits, we observed that the lake surface was the defining morphometric element in assessing the lakes' response to human pressures. The results obtained for the large areas of Lakes I (3.17 ha), III (5.51 ha), IV (6.1 ha) and VIII (4.16 ha) were validated in the field, the degradation by eutrophication and vegetation expansion being evident (Table 2, Fig. 5). Regarding the temporal dynamics of the lacustrine surface, Lake VI represents a particular case, since, its surface has decreased dramatically until it disappeared in 2018; at the opposite pole is Lake I (which is as mentioned above, the only lake in concession and periodically subjected to sediment extraction), Lakes III, IV and VIII, the other four lakes (Lakes II, VII, IX and X) having a surface stability during the last 5 years (Table 2). In terms of perimeter, in 2019, Lake IV covers the most surface $(1.39 \mathrm{~km})$, whereas Lake II $(0.5 \mathrm{~km})$, the smallest (Google Earth $\mathrm{PRO}$, data extraction); this ranking proves a direct proportionality relationship between the two parameters of the lakes - the perimeter and the surface.

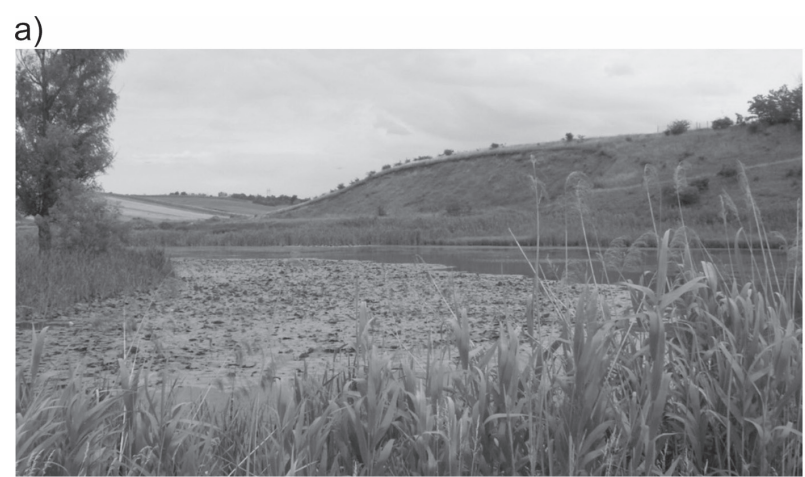

b)

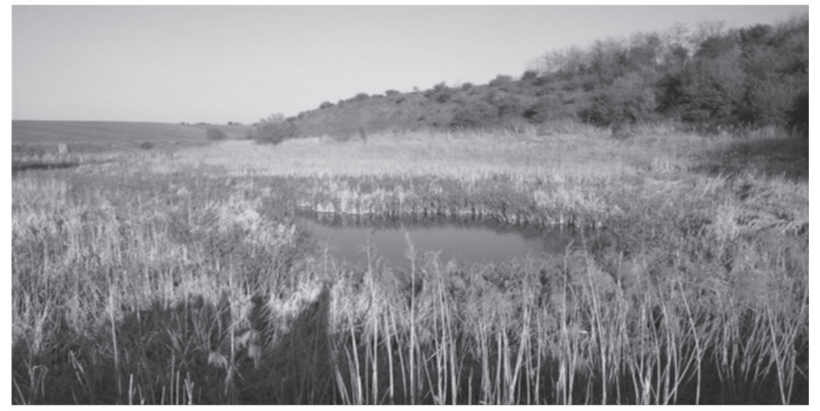

c)

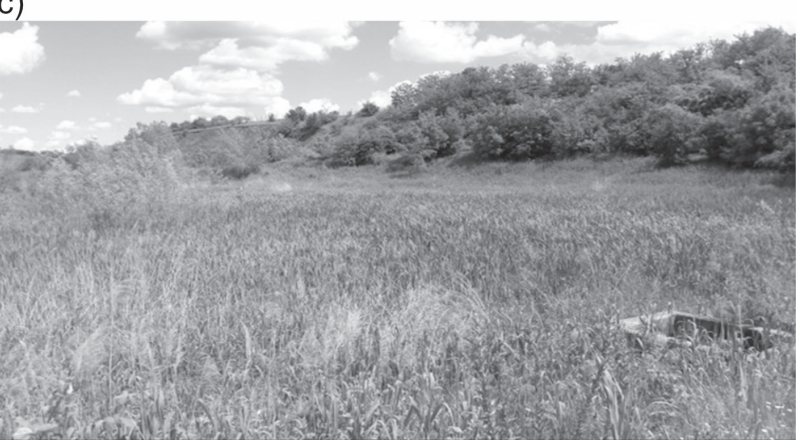

Fig. 5. a) Lake VI with Nuphar lutea (Goga, April 2010); b) Typha expansion in Lake VI (Mititelu, November 2016); c) Lake VI disappearance and vegetation expansion (Mititelu, April 2019).

The above mentioned situation is caused by:

- the reduction of the surface supply by decreasing the underground contribution;

- the blockage of surface spillways with alluvium, causing poor circulation of the Preajba stream between lakes;

- the high altitude difference between the first lakes (Lakes III and IV), which favours the water supply and circulation, resulting in an increase of the lacustrine surface (Table 2). On the other hand, in the case of Lakes V and VI the surface is reduced due to the attenuation of the altitude difference of the dams of Lakes IV $(97.5 \mathrm{~m})$ and V $(90.1 \mathrm{~m})$ over a distance of 290 meters;

- poor maintenance of the spillways from the level of the lakes' dams which causes a high degree of warping, generating the extension of vegetation and of the aquatic surface towards the right bank - Lakes III and VIII. 


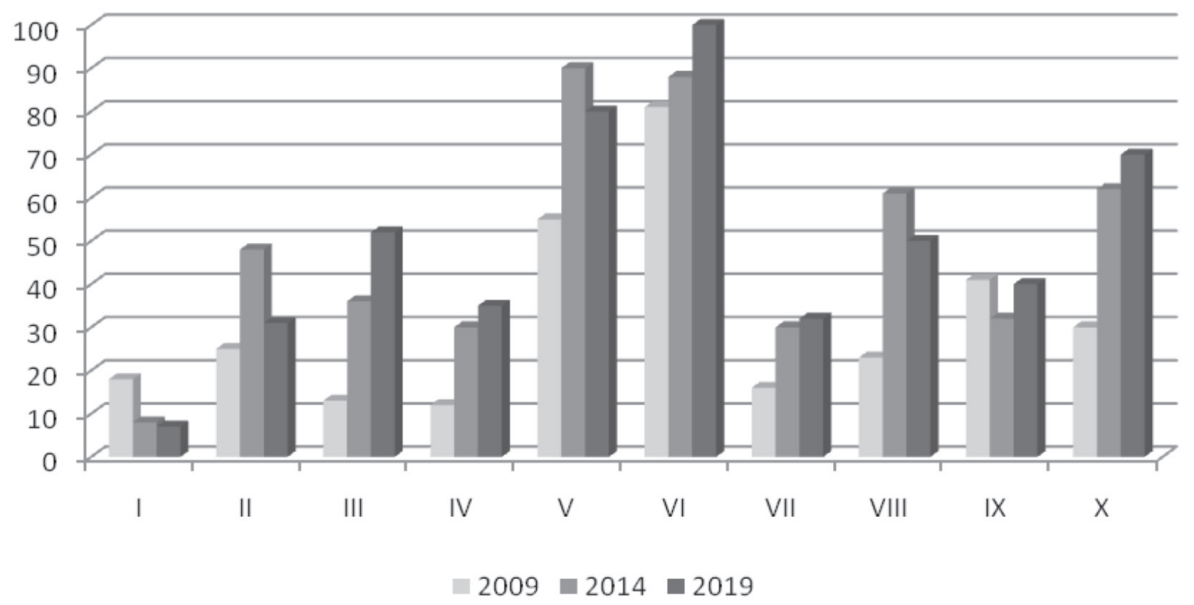

Fig. 6. Temporal dynamics of the vegetation percentage within the Preajba Valley lakes. (Field research and Google Earth PRO data extraction for May 2009, May 2014 and May 2019).

\section{Aquatic Vegetation Response}

The increase of human pressures has led to a progressive process of eutrophication. Most of the Preajba Valley lakes during the observed period are invaded by aquatic and paludous macrophytes, which is a feature of the eutrophic ecosystems.

The anthropic expansion and thus the diminishing of the natural areas can be observed through the changes of the specific biotope and the extension of hydrophilic vegetation in the detriment of water bodies (Fig. 5a-c).

The aquatic vegetation response was completed by determining the extrapolated index of insularity for vegetation, being an edifying parameter. The results obtained from vectoring the hydrofile vegetation developed in May of each year of the study period have shown that the year of 2014 was defining for the expansion of vegetation in the case of lakes II $-47 \%$, V $-88 \%$ and VIII $-60 \%$, and 2019 , in the case of lakes III - $51 \%$, IV-32\%, VI- 100\% and X - 69\% (Fig. 6).

During the last 10 years, the tendency of the vegetation extension has been ascending for Lakes II, III, VI and $\mathrm{X}$, a fact confirmed by the field visits (Fig. 4, 7). For example, in Lake VI the share of vegetation in the summer period increased from 30\% in 2009 to $75 \%$ in 2014 , this lake being under threat of disappearing. The expansion of hydrofile vegetation to the capture of water in the case of lakes V and VI was due to human pressures to increase the tourist and fishing usage of downstream lakes (lakes with greater accessibility) by totally lifting the spillways.

Obtaining the lowest vegetation percentage values for Lake I (2009 - 18\%; 2019 - 5\%) was due to the positive involvement of the human factor through unclogging, restoration of the dam and setting up facilities for recreation and fishing activities. Expanding vegetation at the expense of water bodies determines chemical-physical imbalances of stagnant organisms, which entails a reduction in the number of species that constitute ichtyofauna.

\section{Ichtyofauna Response}

Change in behaviour is usually the first response to human-induced environmental change and represents a key factor in determining whether a species adapts to environmental change or becomes maladapted. In this context, along the Preajba Valley Lakes, changes have been identified over the last decade, especially concerning the zooplankton communities. Most species originate from the pre-existing reophilic ecosystem, to which were added new species such as Esox lucius and Silurus glanis, which were introduced in 2006 in Lake $\mathrm{X}$ by fishermen, the species being brought from both the natural marshes of the Danube's floodplain or from the fish farms.

At present, the fish species from the Preajba Valley lakes are common, with high resistance to changes in the eutrophic environment. Some species were found in a single lake, such as Silurus glanis and Esox lucius (Lake X), Alburnus alburnus and Rutilus rutilus (Lake VII); in two lakes Gymnocephalus cernuus (Lake VII and X) and Sander lucioperca (Lake VII and VIII), or in all ten lakes, the Carassius gibelio species.

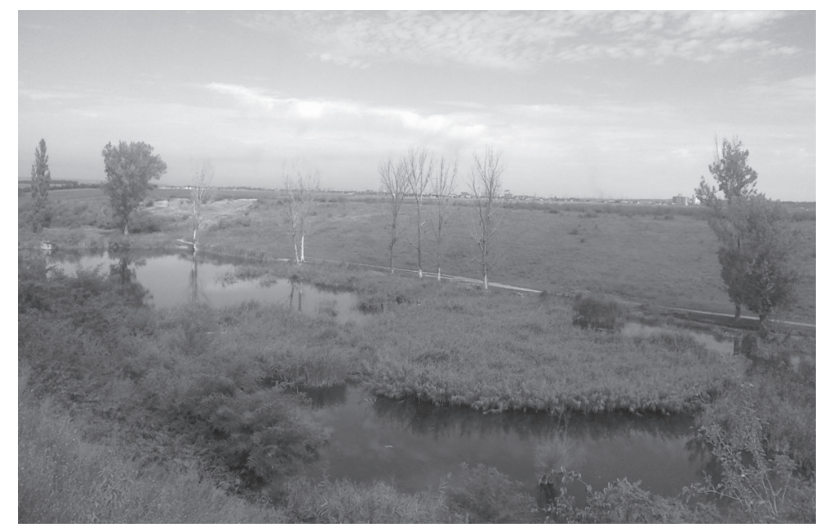

Fig. 7. Extension of vegetation in Lakes II (Simulescu, May 2019). 
The distribution of species in the ten lakes of the Preajba Valley, with a slight agglomeration in Lakes VII and IX, is given by the environmental factors. Due to their ecological features, the Carassius gibelio species is constant along the Preajba Valley (Frequency-86.8\% and Abundence-51.8\%) (Fig. 8), being a species with limited requirements regarding the consumption of oxygen and preferences for the mastic substrate rich in organic detritus. Following the interpretation of quantitative biocenotic indices, it can be concluded that the species Carassius gibelio is closely followed by Perca fluviatilis (F-37.75\%) and Lepomis gibbosus (F-30.2\%) as accessory species. With a low percentage of biocenotic indices ( $\mathrm{F}<\mathrm{a} 25 \%)$ the following are accidental species: Scardinius erythrophthalmus, Pseudorasbora parva, Alburnus alburnus, Cyprinus carchio and Abramis brama (Fig. 8).

\section{Water Quality Response}

From the point of view of the surface water quality, the small reservoirs of the Preajba Valley can be used for fish, as well as for tourist and entertainment purposes. The paper results summarize the present human interactions on the lakes and also highlight the case of the railway accident that happened in the summer of 2018 (Fig. 9), when a considerable amount of biodiesel was spilled into the Preajba stream, representing a unique case of accidental pollution during the researched time interval.

The railway accident produced in August 2018 confirms the existence of asymmetric relations between man and nature. The impact on the soil and water was initially visual (destruction of vegetation, covering the soil and water with a biodiesel pellicle), later samples

\section{Frequency of species}
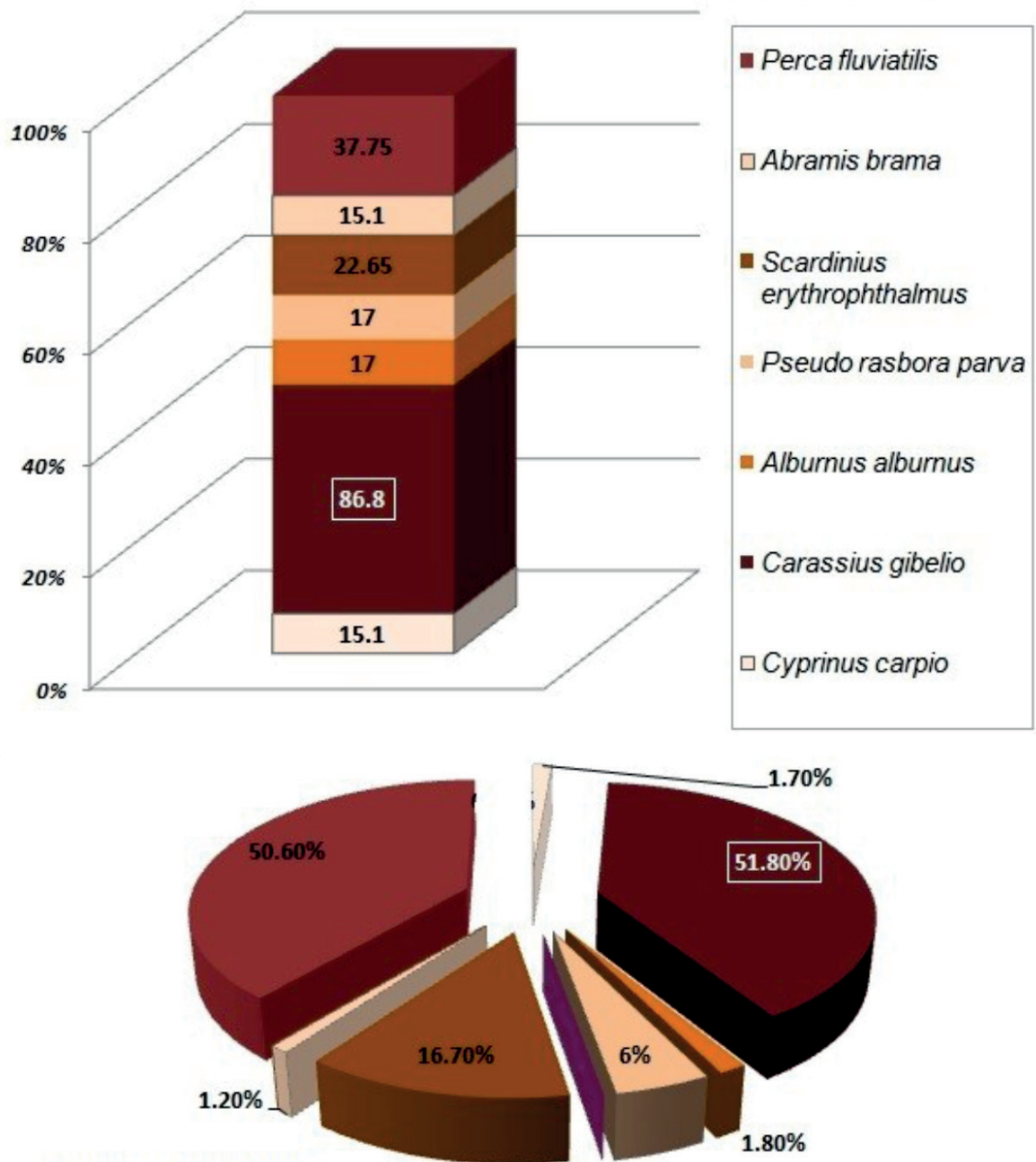

Species abundance
$\square$ Cyprinus carpio
- Carassius gibelio
- Alburnus alburnus
$\square$ Pseudo rasbora parva
- Scardinius erythrophthalmus
$\square$ Abramis brama
- Perca fluviatilis

Fig. 8. Frequency and abundance of Carassius gibelio species within the Preajba Valley lakes. 


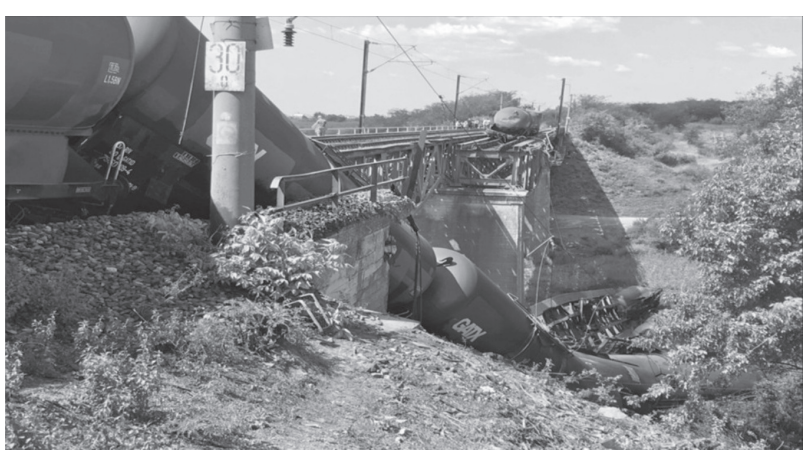

Fig. 9. Railway accident on August 12, 2018 and the discharge of biodiesel in the Preajba stream (the village of Cârcea. Source: www.jurnalulolteniei.ro).

were taken and quality analysis were performed. The involvement of the authorities to maintain the balance of the environment was quite difficult to manage, given the proximity of the protected area. In this regard, the water and soil quality monitoring measures lasted 9 months, because they were carried out in two stages (decontamination stage and conservation stage).

Laboratory analyses of physico-chemical indicators revealed that the hazardous chemicals (methyl esters) affected only the watercourse upstream of the lakes, which meant that the lakes and, implicitly, the protected area weren't affected. The last values of the biodiesel load in the ground and in Preajba creek were below the allowed limit of $2.5 \mathrm{mg} / \mathrm{dm}^{3}$. Instead, the high $\mathrm{pH}\left(8.2 \mathrm{pH}\right.$ unit), fixed residue $\left(384 \mathrm{mg} / \mathrm{dm}^{3}\right), \mathrm{NO}_{2}$ $\left(0.124 \mathrm{mg} / \mathrm{dm}^{3}\right), \mathrm{NO}_{3}\left(16.28 \mathrm{mg} / \mathrm{dm}^{3}\right)$ and chemical

a)

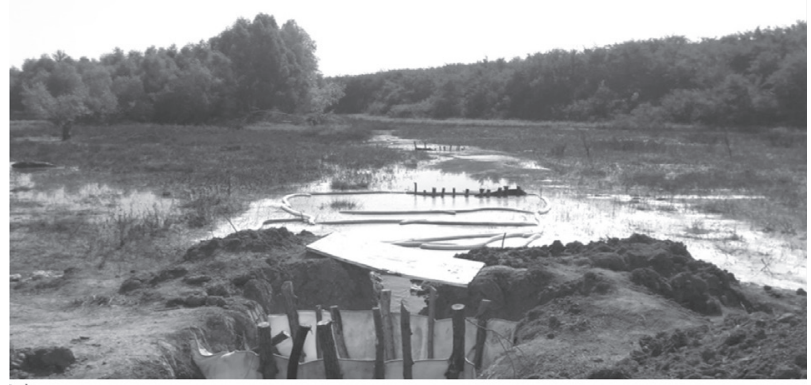

b)

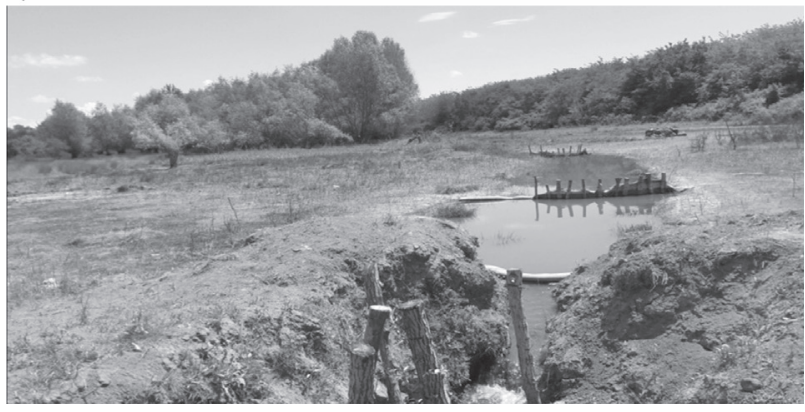

Fig. 10. Ecological works to remove biodiesel: a) installing of absorbent floating dams in August 2018 and b) cleaning of vegetation and soil May 2019 (Photos by Mititelu). oxygen demand - Chloride $\left(49.7 \mathrm{mg} / \mathrm{dm}^{3}\right)$ confirms the high degree of eutrophication [32] due to the poor management of the maintenance work, leading to the abundance of vegetation macrophytes and endangering the ichthyofauna.

Apart from the verification of the water quality in the Preajba stream, the spring and Lake I sector, which was carried out by the regional authorities (Agency for Environmental Protection and Jiu Water Basin Administration, after the samples taken by the authors), the railway transport company carried out ecological works by applying the Oil Stop technology. Biodiesel from the watercourse was eliminated by applying absorbent floating dams and was treated with a biodegradable solution (Fig. 10 a). Subsequently, the vegetation and the soil in the affected areas were treated with biodegradable solution to neutralize the biodiesel (Fig. 10 b).

The measured $\mathrm{pH}$ values indicated pollution with inorganic compounds. Alkaline $\mathrm{pH}$ is found especially where aquatic macrophytes are abundant, and through the process of photosynthesis, a large amount of $\mathrm{CO}_{2}$ is accumulated in the water. The high oxygen consumption is supported by the values of the chemical oxygen demand - CCOCr, that shows the excessive development of the planktonic communities, which can generate the death of fishes (Table 3). The high values of nitrites and nitrates are due to the autumn season when, as the consumption of the vegetative processes decreases, the nitrate content begins to increase. At the same time, they indicate a strong conversion of ammonia into nitrites, with a negative impact on the flora and fauna. The main physico-chemical parameters highlight the water pollution from Lake VII, in which cas the weakening of the defence mechanisms of fishe, and the insufficient oxygenation of the water favours the phenomenon of parasitism [33, 34].

Table 3. Main parameters of the water quality of Lake VII.

\begin{tabular}{|c|c|c|c|}
\hline \multirow{2}{*}{ Parameters } & \multicolumn{2}{|c|}{ Recorded values } & \multirow{2}{*}{$\begin{array}{c}\text { Allowed values } \\
161 / 2006 \\
\text { Ministerial Order }\end{array}$} \\
\hline & $\begin{array}{l}\text { October } \\
2014\end{array}$ & $\begin{array}{l}\text { November } \\
2019\end{array}$ & \\
\hline $\begin{array}{c}\mathrm{pH} \\
\text { (pH unit) }\end{array}$ & 8.29 & 8.2 & $6.5-8.5$ \\
\hline $\begin{array}{l}\text { Fixed residue } \\
\quad\left(\mathrm{mg} / \mathrm{dm}^{3}\right)\end{array}$ & 348 & 384 & 750 \\
\hline $\begin{array}{l}\text { Nitrites }\left(\mathrm{NO}_{2}\right) \\
\quad\left(\mathrm{mg} / \mathrm{dm}^{3}\right)\end{array}$ & $<0.01$ & 0.124 & 0.1 \\
\hline $\begin{array}{l}\text { Nitrates }\left(\mathrm{NO}_{3}\right) \\
\quad\left(\mathrm{mg} / \mathrm{dm}^{3}\right)\end{array}$ & 13.2 & 16.28 & 13 \\
\hline $\begin{array}{l}\text { Chloride }(\mathrm{Cl}) \\
\left(\mathrm{mg} / \mathrm{dm}^{3}\right)\end{array}$ & 50 & 49.7 & 50 \\
\hline $\begin{array}{l}\operatorname{CCOCr}\left(\mathrm{O}_{2}\right) \\
\left(\mathrm{mgO}_{2} / \mathrm{dm}^{3}\right)\end{array}$ & 5.8 & 8.4 & 25 \\
\hline \multicolumn{4}{|c|}{$\begin{array}{l}\text { (Data source: Quality laboratory, Dolj Environmental } \\
\text { Protection Agency, after the samples taken by the authors) }\end{array}$} \\
\hline
\end{tabular}


In this sense, the proposed measures aimed at the ihtio-parasitological control in these lakes, are especially preventive, aimed at destroying the excessively developed macrophyte vegetation.

\section{Management Implications}

The research indicated that human activities are the driving factors which cause the shrinkage of the Preajba Valley in the context of the suburban study area. In this regard and according to sustainable policies, it's necessary that the authorities and the locals take measures, regarding: fishing prohibition of any fish species; cleaning the banks of the lakes by cutting down trees and shrubs; limiting works that prevent migration, reproduction or endangerment of existing fish populations; clearing the lakes by harvesting submerged plants, extracting mud and sand.

Additionally, the need to establish rigorous criteria for granting construction permits, as well as the way in which they are realized, as the anthropic extension will cause the disappearance of Lakes III, V and X in the next 10 years. Thus, of great importance is the awareness of the locals in the sense of respecting the status of the protected area. Moreover, the option of not polluting the environment by improper disposal of waste, in conjunction with the restoration of the surface spillways, will cause an increase of oxygenation of the water and implicitly a decrease of the eutrophic vegetation.

Therefore, we can say that the problem of the lakes in Preajba Valley is a typical one for the environmental changes, complementary to a suburban lacustrine ecosystem.

\section{Conclusions}

The results highlight the fact that Craiova's urban system and the Preajba stream-lakes system are far from being isolated and static, considering that there is a constantly changing relation and influence between them.

The theoretical significance and contribution to the field of research lies in the choice of the methodology, which, after being verified at a micro-scaled level, can later be applied at an international level. Our results suggest the dependent sensitivity of aquatic ecosystem to human pressures, which has general management implications. The limitations of the study were generated by the poor collaboration with the parties interested in the current status and management of the protected area of the Preajba-Făcai lake complex, determining the authors of this study to carry out the field visits and measurements on their own. In this respect, improved results can be obtained by using high-performance sonar devices in analysing the biotopes and biocenosis of lakes.
Future research directions aim to correlate anthropogenic pressures with natural factors (climatic and hydrological) in the study of the degradation of the lake ecosystem. At the same time, the aim is to establish concrete measures for the management of the protected area, given the difficulties of finding the balance between man and nature in a suburban environment.

\section{Acknowledgements}

We would like to thank the institutions that facilitated this research and provided support for laboratory analysis (Environmental Protection Agency, Dolj County) and field research (The Oltenia Museum, Section of Natural Sciences). Thanks are also addressed to Domino NGO for their previous research of the lacustrine complex in the Preajba-Făcăi protected area.

The authors are grateful to the editor and the anonymous reviewers for their valuable comments and helpful suggestions. The authors contributed equally to this work.

\section{Conflict of Interest}

The authors declare no conflict of interest.

\section{References}

1. DUMITRAŞCU M., MOCANU I., MITRICĂ B., DRAGOTĂ C., GRIGORESCU I., DUMITRICĂ C. The assessment of socio-economic vulnerability to drought in Southern Romania (Oltenia Plain). International journal of disaster risk reduction, 27, 142, 2018.

2. BOENGIU S., VLADUT A., MARINESCU E. Conditions of gully development within piedmont areas with examples from the western part of the Getic Piedmont, Romania. Journal of environmental biology, 33 (2), 407, 2012.

3. WANG H., MAO L., LU S., YING J., JIANG Q., YUAN R., XIAOFENG L., WANG M., ZHAO D. What determines the change of lakes in large cities under climate change and anthropogenic activities? Evidence from Eastern China. Polish Journal of Environmental Studies, 28 (3), 1949, 2019.

4. PENALUNA B.E., REEVES G. H., BARNETT Z.C., BISSON P. A., BUFFINGTON J. M., DOLLOFF C. A., FLITCROFT R. L., LUCE C. H., NISLOW K. H., ROTHLISBERGER J.D., WARREN JR M. L. Using natural disturbance and portfolio concepts to guide aquatic-riparian ecosystem management. Fisheries, 43 (9), 406, 2018.

5. DEARING J. A., BATTARBEE R.W., DIKAU R., LAROCQUE I., OLDFIELD F. Human-environment interactions: learning from the past. Reg Environ Change, 6, $1,2006$.

6. PETRIŞOR A.I., IANOŞ I., TĂLÂNGĂ C. Land cover and use changes focused on the urbanization processes in Romania. Environmental Engineering \& Management Journal (EEMJ), 9 (6), 2010. 
7. QIAO L. Reform on Current Suburb Water Environment Management. Value Engineering, 18, 1, 2012.

8. MIERZEJEWSKA L. Sustainable development of a city: Systemic approach. Problemy ekorozwoju - Problems of sustainable development, 12 (1), 71, 2017.

9. GONZALEZ-VALENCI R., MAGAÑA-RODRIGUEZ F., SEPULVEDA-JAUREGUI A., AGUIRREZABALACAMPANO, T., GERARDO-NIETO O., \& THALASSO F. A simple model for the numerical characterization of spatiotemporal variability in aquatic ecosystems. Aquatic Sciences, 81 (4), 58, 2019.

10. FINLAY J.C., SMALL G.E., STERNER R.W. Human influences on nitrogen removal in lakes. Science, 342 (6155), 247, 2013.

11. LÜRLING M., MACKAY E., REITZEL K., SPEARS B. M. Editorial - A critical perspective on geo-engineering for eutrophication management in lakes. Water Research, 97 (15), 1, 2016.

12. SIRODOEV I., CHEVAL, S., DUMITRESCU A., MERCIU C., VAIDIANU N., PARASCHIV M., SCHVAB A., SAGHIN I., PREFAC Z. Contribution of the built-up space to the creation of urban heat island in Bucharest Municipality. Journal of Environmental Protection and Ecology, 16 (4), 1337, 2015.

13. BRUNO D., BELMAR O., SÁNCHEZ-FERNÁNDEZ D., GUARESCHI S., MILLÁN A., VELASCO J. Responses of Mediterranean aquatic and riparian communities to human pressures at different spatial scales. Ecological Indicators, 45, 456, 2014.

14. DIACONU D.C., BRETCAN P., PEPTENATU D., TANISLAV D., MAILAT E. The importance of the number of points, transect location and interpolation techniques in the analysis of bathymetric measurements. Journal of hydrology, 570, 774, 2019.

15. GRANTHAM T.E., FIGUEROA R., PRAT N. Water management in mediterranean river basins: a comparison of management frameworks, physical impacts, and ecological responses. Hydrobiologia, 719 (1), 451, 2013.

16. LIERMANN C.R., NILSSON C., ROBERTSON J., NG R.Y. Implications of dam obstruction for global freshwater fish diversity. BioScience, 62 (6), 539, 2012.

17. LIU G., WANG J., LI S., LI J., DUAN P. Dynamic evaluation of ecological vulnerability in a lake watershed based on RS and GIS technology. Pol. J. Environ. Stud, 28, 1785,2019

18. MOOIJ W.M., VAN WIJK D., BEUSEN A.H., BREDERVELD R.J., CHANG M., COBBEN M.M., DEANGELIS D.L., DOWNING A., GREEN P., GSELL A.S., HUTTUNEN I., JANSE J.H., JANSSEN A. BG., HENGEVELD G., KONG X., KRAMER L., KUIPER J., LANGAN S., NOLET B. A., NUIJTEN R.J.M., STROKAL M., TROOST T.A., VAN DAM A.A., TEURLINCX S. Modeling water quality in the Anthropocene: directions for the next-generation aquatic ecosystem models. Current opinion in environmental sustainability, 36, 85, 2019.

19. GILL J.C., MALAMUD B.D. Anthropogenic processes, natural hazards, and interactions in a multi-hazard framework. Earth-Science Reviews, 166, 246, 2017.

20. ELIZBARASHVILI N., DVALASHVILI G., SULKHANISHVILI N. Selection principles and focuses of landscape planning of protected areas. International Journal of Geoheritage and Parks, 7 (1), 33, 2019.
21. CUMMING G.S. The relevance and resilience of protected areas in the Anthropocene. Anthropocene, 13, 46, 2016.

22. NAGENDRA H., MAIROTA P., MARANGI C., LUCAS R., DIMOPOULOS P., HONRADO J.P., NIPHADKAR M., MÜCHER C.A., TOMASELLI V., PANITSA M., TARANTINO C., MANAKOS I., BLONDA P. Satellite Earth observation data to identify anthropogenic pressures in selected protected areas. International Journal of Applied Earth Observation and Geoinformation, 37, 124, 2015.

23. DUAN P., WANG Y., YIN P. Remote sensing applications in monitoring of protected areas: A bibliometric analysis. Remote Sensing, 12 (5), 772, 2020.

24. AVRAM M., IONUȘ O. Spatial relations of the Preajba Valley Lakes evolution reflected on cartographic documents, Lakes, reservoirs and ponds, 9 (2), 123, 2015.

25. Atlas of Water Cadastral Survey Romania. Part 1 Morpho-hydrographic data on the surface hydrographic network. Ministry of Environment, Bucharest 694, 1992 [In Romanian].

26. IONUȘ O. Discursive Relationship between Human Development, Environment and Sustainability. In Environment and Ecology at the Beginning of $21^{\text {st }}$ Century; Efe R., Bizzarri C., Curebal I., Nyusupova E. Edits., Publisher: Kliment Ohridski University Press, Sofia, Bulgaria, 821, 2015.

27. MITITELU-IONUȘ O., AVRAM M.-E. Spatial and temporal dynamics of human pressure within the Preajba catchment area, Romania. Forum Geografic, XV (1), 34, 2016.

28. IONUȘ O., GOGA C.I., AVRAM M. Morphological and morphometric analysis of the Preajba Valley Lakes (Dolj county, Romania). Lakes, reservoirs and ponds, 8 (2), 68, 2014.

29. HENDRY A.P., GOTANDA K.M, SVENSSON E.I. Human influences on evolution, and the ecological and societal consequences. Biological sciences, Phil. Trans. R. Soc. B, 372, 20160028, 2017.

30. GOGA C.I. Basic data on the piscicultural communities from the hydrographic basin Preajba Valley. Oltenia. Studies and Communication. Natural Sciences. Oltenia Museum, 25, 165, 2009.

31. LACOURSIËRE-ROUSSEL A., CÔTÉ G., LECLERC V., BERNATCHEZ L. Quantifying relative fish abundance with eDNA: a promising tool for fisheries management. Journal of Applied Ecology, 53 (4), 1148, 2016.

32. Order 16 for the approval of the Norm regarding the classification of surface water quality in order to establish the ecological status of water bodies, Ministry of the Environment and Water Management, Romania, 2006 [In Romanian].

33. GOGA C.I., TÎMBURESCU C., IONUŞ O. Ectoparasitic thermophilous crustacean at fish species from Preajba Valley reservoirs (Dolj, Romania). Oltenia. Studies and communications. Natural Sciences. Museum of Oltenia, Craiova, 32 (2), 61, 2016.

34. GOGA C.I., MITITELU-IONUȘ O., TÎMBURESCU C. Studies of Chilodonella Cyprini Sin. (Piscicola) infection (Chilodonellidae, Chilodonella) in the Preajba Valley River Basin (Romania), Int. J. of Environmental Pollution \& Environmental Modelling, 1 (2), 39, 2018. 